Cordova Jurnal

ISSN (P) 2302-3155,

(e) 2714-5808

Vol. 9, No. 12019
Jurnal kajian Bahasa dan Budaya terbit 2 kali setahun oleh UPT. Pusat Pengembangan

Bahasa (P2B) UIN Mataram. Tersedia online pada

https://journal.uinmataram.ac.id/index.php/cordova

\title{
PENGEMBANGAN MULTIMEDIA \\ DALAM PEMBELAJARAN (المفردات )KOSAKATA BAHASA ARAB DI PESMA AL-HIKAM MALANG
}

\author{
Moh. Nadhif \\ Dosen di UIN Maulana Malik Ibrahim Malang \\ Mohnadhif22@yahoo.com
}

\begin{abstract}
Abstrak
Penelitian ini bertujuan untuk: (1) mengembangkan multimedia pembelajaran kosakata Arab Pesma Al-Hikam Malang; mengungkapkan kualitas multimedia pembelajaran ditinjau dari aspek isi, pembelajaran, tampilan, dan pemrograman; (3) mengetahui aspek daya tarik multimedia pembelajaran yang dikembangkan; mengetahui ketuntasan belajar santri setelah belajar dengan menggunakan multimedia pembelajaran kosakata Arab Pesma Al-Hikam Malang.

Penelitian ini adalah penelitian pengembangan. Validator penelitian ini adalah satu orang ahli bidang studi bahasa Arab dan satu orang ahli multimedia pembelajaran. Subjek coba penelitian terdiri dari tiga santri untuk uji coba satu-satu dan dua puluh santri untuk uji coba kelompok besar. Instrumen yang digunakan untuk penelitian ini adalah angket, pedoman observasi, dan soal pre-test dan post-test. Data dianalisis dengan menggunakan teknik statistik deskriptif.

Hasil penelitian ini adalah: (1) pengembangan multimedia pembelajaran kosakata bahasa Arab kelas I Pesma Al-Hikam Malang melalui enam langkah, yaitu: menganalisis, mendesain, memproduksi, memvalidasi, merevisi, dan mengujicoba; (2) kualitas multimedia pembelajaran yang dikembangkan ditinjau dari aspek isi, pembelajaran, tampilan, dan pemrograman adalah baik. Dengan menggunakan rentang skor 1 sampai 5, aspek isi menunjukkan skor rata-rata 3,75, aspek pembelajaran menunjukkan skor rata-rata 3,71, aspek tampilan


Cordova Jurnal

ISSN (P) 2302-3155,

(e) 2714-5808

Vol. 9, No. 12019
Jurnal kajian Bahasa dan Budaya terbit 2 kali setahun oleh UPT. Pusat Pengembangan Bahasa (P2B) UIN Mataram. Tersedia online pada https://journal.uinmataram.ac.id/index.php/cordova

menunjukkan skor rata-rata 3,87, dan pemrograman menunjukkan skor rata-rata 3,75; (3) aspek daya tarik menunjukkan bahwa multimedia pembelajaran yang dikembangkan sangatmenarik: pada uji coba satusatu, dari tiga santri yang diobservasi, dua santri menunjukkan daya tarik produk sangat menarik, satu siswa menunjukkan daya tarik produk menarik; pada uji coba kelompok besar, dari dua puluh santri, dua belas santri menunjukkan daya tarik produk sangat menarik, delapan santri menunjukkan daya tarik produk menarik; dan (4) penggunaan multimedia pembelajaran kosakata bahasa Arab berdampak baik terhadap ketuntasan belajar santri: pada uji coba kelompok besar, dari 20 santri, terdapat 19 santri (95\%) yang tuntas belajar dalam pembelajaran kosakata bahasa Arab kelas I Pesma Al-Hikam Malang.

Kata Kunci: Pengembangan, Multimedia, Kosakata

\section{PENDAHULUAN}

Hasil pengamatan peneliti, pembelajaran bahasa Arab di Pesantren selama ini masih bersifat konvensional. Dalam mengajar ustadz hanya mengandalkan metode ceramah secara klasikal. Guru/Ustadz kurang menggunakan media pendukung selain buku. Metode pembelajaran seperti ini kurang memenuhi prinsip-prinsip pembelajaran yang efektif dan kurang memberdayakan potensi siswa. Kegiatan belajar mengajar seharusnya mampu mengoptimalkan semua potensi siswa untuk menguasai kompetensi yang diharapkan. Proses belajar mengajar sebaiknya dilandasi dengan prinsip-prinsip: (1) berpusat pada siswa, (2) mengembangkan kreativitas siswa, (3) menciptakan kondisi menyenangkan dan menantang, mengembangkan beragam kemampuan yang bermuatan nilai, (5) menyediakan pengalaman belajar yang beragam, dan (6) belajar melalui berbuat.

Berdasarkan hal tersebut di atas, baik ustadz maupun siswa di pesantren memerlukan adanya inovasi media pembelajaran. Inovasi 
Cordova Jurnal

ISSN (P) 2302-3155,

(e) 2714-5808

Vol. 9, No. 12019
Jurnal kajian Bahasa dan Budaya terbit 2 kali setahun oleh UPT. Pusat Pengembangan

Bahasa (P2B) UIN Mataram. Tersedia online pada

https://journal.uinmataram.ac.id/index.php/cordova

media pembelajaran tersebut digunakan untuk meningkatkan kualitas pembelajaran. Salah satu produk teknologi yang dapat digunakan sebagai inovasi dalam pembelajaran adalah computer dan laptop. Hal tersebut sesuai dengan pernyataan Herman Dwi Surjono (1995: 2) bahwa komputer sebagai salah satu produk teknologi dinilai tepat digunakan sebagai alat bantu pengajaran.

Keberadaan komputer yang telah meluas sampai tingkat sekolah dasar saat ini belum banyak digunakan untuk meningkatkan prestasi khususnya dalam pembelajaran bahasa Arab. Keadaan ini sejalan dengan pernyataan Herman Dwi Surjono (1999: 2) bahwa penggunaan komputer dalam bidang pendidikan hingga saat ini belum maksimal. Multimedia pembelajaran merupakan komponen sistem penyampaian pengajaran yang dapat digunakan dalam mendukung proses pembelajaran. Pengembangan multimedia dilandasi oleh persepsi bahwa pembelajaran akan berlangsung dengan baik, efektif, dan menyenangkan jika didukung oleh media pembelajaran yang dapat menarik minat dan perhatian siswa. Oleh karena itu, pengembang perlu memahami konsep, model, prinsip, desain, dan evaluasi multimedia pembelajaran.

\section{Multimedia}

Definisi multimedia pembelajaran terbagi menjadi dua yaitu definisi sebelum tahun 1980-an dan definisi sesudah tahun 1980-an. Sebelum tahun 1980-an atau pada era 60-an, menurut Barker \& Tucker, 1990 (Sunaryo Soenarto, 2005: 116), multimedia diartikan sebagai kumpulan dari berbagai peralatan media berbeda yang digunakan untuk presentasi. Dalam pengertian ini multimedia diartikan sebagai 5 ragam media yang digunakan untuk penyajian materi pelajaran, misalnya penggunaan wall chart atau grafik yang dibuat di atas kertas karton yang ditempelkan di dinding.Tan Seng Chee \& Angela F. L. Wong (2003: 217) menyatakan bahwa multimedia secara tradisional merujuk kepada penggunaan beberapa media, sedangkan multimedia 
Cordova Jurnal

ISSN (P) 2302-3155,

(e) 2714-5808

Vol. 9, No. 12019
Jurnal kajian Bahasa dan Budaya terbit 2 kali setahun oleh UPT. Pusat Pengembangan

Bahasa (P2B) UIN Mataram. Tersedia online pada

https://journal.uinmataram.ac.id/index.php/cordova

pada zaman sekarang merujuk kepada penggunaan gabungan beberapa media dalam penyajian pembelajaran melalui komputer.

Setelah tahun 1980-an, multimedia didefinisikan sebagai penyampaian informasi secara interaktif dan terintegrasi yang mencakup teks, gambar, suara, video atau animasi (Hackbarth, 1996; Philips, 1997). Hackbarth (1996: 229) menekankan

bahwa hypermedia dan hypertext termasuk multimedia interaktif berbasis komputer.

Philips (1997: 8) menekankan pada komponen interaktivitas yang menunjuk kepada

proses pemberdayaan pengguna untuk mengendalikan lingkungan melalui komputer.

Definisi setelah tahun 1980-an tersebut di atas lebih menekankan pada multimedia sebagai sistem komunikasi interaktif berbasis komputer yang mampu menciptakan, menyimpan, menyajikan, dan mengakses kembali informasi teks, grafik, suara, dan video atau animasi. Sejalan dengan hal tersebut, Agnew, Kellerman \& Meyer (1996: 8) menyatakan bahwa istilah multimedia lebih terfokus pada interaktivitas antara media dengan pemakai media. Constantinescu (2007: 2) menyatakan bahwa "Multimedia refers to computer-based systems that use varioustypes of content, such as text, audio, video, graphics, animation, and interactivity". Maksudnya adalah bahwa multimedia merujuk kepada sistem berbasis computer yang menggunakan berbagai jenis isi seperti teks, audio, video, grafik, animasi, dan interaktivitas.

Multimedia pembelajaran bermanfaat dalam beberapa situasi belajar mengajar. Philips (1997: 12) menyatakan bahwa "IMM has the potential to accommodate people with different learning style". Artinya adalah bahwa multimediainteraktif dapat mengakomodasi cara belajar yang berbeda-beda. Lebih lanjut Philips(1997: 12) menyatakan bahwa multimedia interaktif memiliki potensi untukmenciptakan suatu lingkungan multisensori yang mendukung cara belajar tertentu.

Berdasarkan hal tersebut, multimedia dalam proses belajar mengajar dapat digunakan dalam tiga fungsi. Pertama, multimedia 
Cordova Jurnal

ISSN (P) 2302-3155,

(e) 2714-5808

Vol. 9, No. 12019
Jurnal kajian Bahasa dan Budaya terbit 2 kali setahun oleh UPT. Pusat Pengembangan

Bahasa (P2B) UIN Mataram. Tersedia online pada

https://journal.uinmataram.ac.id/index.php/cordova

dapat berfungsi sebagai alat bantu instruksional. Kedua, multimedia dapat berfungsi sebagai tutorial interaktif, misalnya dalam simulasi. Ketiga, multimedia dapat berfungsi sebagai sumber petunjuk belajar, misalnya, multimedia digunakan untuk menyimpan serangkaian slide mikroskop atau radiograf.

Dalam pengembangan multimedia pembelajaran perlu diperhatikan tahaptahap tertentu yang harus dilalui. Hal ini dilakukan agar dapat menghasilkan suatu produk mutimedia pembelajaran yang baik dan layak untuk digunakan sebagai media pembelajaran. Luther, 1994 (Ariesto Hadi Sutopo, 2003: 32-48) mengungkapkan enam tahap pengembangan multimedia pembelajaran, yaitu concept, design, materialcollecting, assembly, testing, dan distribution.

Philips (1997: 37) menyajikan suatu model dalam mengembangkan multimedia pembelajaran interaktif yang disebut waterfall model (model air terjun). Dalam model ini, perbaikan dapat dilakukan pada saat pembuatan desain atau sebelum pembuatan produk dimulai. Hal tersebut dimaksudkan untuk mencapai kesempurnaan desain multimeda pembelajaran yang dikembangkan. Model air terjun ini menggunakan pendekatan interaktif partisipatori. Langkah-langkah model air terjun adalah: (1) melakukan analisis kebutuhan dan definisi, (2) mendesain perangkat lunak dan sistem, (3) melakukan implementasi dan ujicoba, dan (4) melakukan ujicoba sistem.

Menurut Arief S. Sadiman, et al. (2006: 100), pengembangan media meliputi enam langkah, yaitu: (1) menganalisis kebutuhan dan karakteristik siswa, (2) merumuskan tujuan instruksional, (3) merumuskan materi secara terperinci, (4) mengembangkan alat pengukur keberhasilan, (5) menulis naskah media, dan (6) mengadakan tes dan revisi. Sementara itu, Satya Adi (2003: 5-6) menyatakan bahwa proses pengembangan multimedia pembelajaran mengikuti lima langkah, yaitu: (1) melakukan proses analisis yaitu menemukan kebutuhan apa saja yang diperlukan untuk membuat multimedia; (2) membuat desain multimedia yaitu membuat storyboard atau alur cerita; (3) melakukan pengembangan yaitu membuat motioneffect, transisi, 
Cordova Jurnal

ISSN (P) 2302-3155,

(e) 2714-5808

Vol. 9, No. 12019
Jurnal kajian Bahasa dan Budaya terbit 2 kali setahun oleh UPT. Pusat Pengembangan

Bahasa (P2B) UIN Mataram. Tersedia online pada

https://journal.uinmataram.ac.id/index.php/cordova

struktur navigasi, dan data variabel; (4) melaksanakan evaluasi yaitu menguji produk dengan melibatkan audience yang sesungguhnya; dan (5) melakukan pendistribusian yaitu mengemas hasil karya untuk didistribusikan.

Multimedia yang dikembangkan pada penelitian ini adalah multimedia dalam pembelajaran kosakata bahasa Arab kelas I Pesma AlHikam Malang. Penelitian ini mengembangkan multimedia pembelajaran model tutorial yang dapat digunakan. 8 dalam pembelajaran baik secara klasikal maupun individual. Dua topik pembelajaran yang termuat di dalam program multimedia yang dikembangkan yaitu Clothes dan Types of Transportation. Pembelajaran bahasa pada aspek pembelajaran kosakata bahasa Arab pada penelitian ini didasari oleh salah satu karakteristik siswa pesantern adalah pemula dalam belajar bahasa Arab.

\section{Kosakata}

Istilah kosakata dalam bahasa Indonesia sejajar dengan istilah perbendaharaan kata atau leksikon. Membicarakan kosakata berarti membicarakan suatu bidang bahasa yang disebut leksikologi atau ilmu kosakata. Leksikologi atau ilmu kosakata adalah ilmu yang mempelajari seluk beluk kata. Abu Bakar Sulaiman, A. Gani \& Syafri K. (1986: 6) menyatakan bahwa kata kosakata berasal dari bahasa Sansekerta koca dan katha. Kedua kata tersebut diserap ke dalam bahasa Indonesia sebagai kata majemuk.

Rivers (Nunan, 1991: 117) menyatakan bahwa kosakata merupakan hal yang penting agar dapat menggunakan bahasa kedua (second language). Tanpa kosakata yang luas, seseorang tidak akan dapat menggunakan struktur dan fungsi bahasa dalam komunikasi secara komprehensif. Tarigan (1986: 2) menyatakan bahwa kualitas berbahasa seseorang tergantung pada kualitas kosakata yang dimiliki. Makin kaya kosakata yang dimiliki maka makin besar pula kemungkinan terampil berbahasa. Berdasarkan uraian pendapat di atas, dapat dinyatakan bahwa kosakata adalah kata 9 kata yang dimiliki suatu bahasa atau 
Cordova Jurnal

ISSN (P) 2302-3155,

(e) 2714-5808

Vol. 9, No. 12019
Jurnal kajian Bahasa dan Budaya terbit 2 kali setahun oleh UPT. Pusat Pengembangan

Bahasa (P2B) UIN Mataram. Tersedia online pada

https://journal.uinmataram.ac.id/index.php/cordova

seseorang yang membentuk bahasa yang bersangkutan atau dipakai oleh orang atau kelompok masyarakat yang bersangkutan.

Salah satu alasan mengapa guru membelajarkan kosakata adalah untuk memfasilitasi siswa dalam meningkatkan pemahaman terhadap bacaan (Pikulski \& Templeton, 2004: 5). Pengetahuan tentang kosakata adalah pusat keahlian dalam berbahasa. Oleh karena itu, pembelajaran kosakata merupakan sesuatu yang sangat penting. Dalam pembelajaran kosakata diperlukan adanya prosedur dan pendekatan. Pembelajaran kosakata dalam hal ini menyangkut mengajar dan belajar kosakata.

Nation (2001: 107-108) menyebutkan tiga prosedur mengajar kosakata, yaitu: recycled words, the second-hand cloze, dan the vocabulary interview. Dalam recycledwords, prosedur mengajar kosakata bergerak dari receptive use ke productive use yang berfokus pada belajar yang disengaja. Dalam the second-hand cloze, prosedur mengajar kosakata meliputi tiga langkah yaitu siswa membaca teks yang mengandung kosakata sasaran, siswa dengan sengaja belajar kosakata, dan siswa diberikan cloze passages yang merupakan ringkasan dari apa yang sesungguhnya mereka baca. Dalam the vocabulary interview, siswa diberi kesempatan untuk melakukan tanya jawab kepada guru atau kepada siswa lain tentang kosakata tertentu.Salah satu tujuan prosedur ini adalah untuk membuat siswa memperhatikan aspek-aspek mengetahui suatu kata.

Menurut Lado (1979: 121-126), ada beberapa langkah yang dapat diterapkan dalam pembelajaran kosakata yaitu: (1) mendengarkan kata, (2) mengucapkan kata, (3) memahami makna, (4) membuat ilustrasi dalam bentuk kalimat, (5) melakukan

latihan dalam pengekspresian makna, (6) mengucapkan kata tersebut dengan suara keras, dan (7) menulis kata-kata tersebut. Sitorus (1993: 3) menyatakan bahwa kata-kata yang terdapat dalam kelompok, golongangolongan, dan dalam suatu perangkat-perangkat selalu lebih mudah untuk dipelajari. Lebih lanjut Sitorus (1993: 4) mengungkapkan ada dua cara mempelajari kosakata dalam pengelompokan yaitu kelompok kata 
Cordova Jurnal

ISSN (P) 2302-3155,

(e) 2714-5808

Vol. 9, No. 12019
Jurnal kajian Bahasa dan Budaya terbit 2 kali setahun oleh UPT. Pusat Pengembangan

Bahasa (P2B) UIN Mataram. Tersedia online pada

https://journal.uinmataram.ac.id/index.php/cordova

yang mempunyai satu dasar umum dan kelompok kata yang mempunyai hubungan dalam pengertian.

Piaget (Hoskisson \& Tompkins, 1987: 11) menyatakan bahwa siswa pesantren adalah concrete thinkers (pemikir konkrit). Mereka belajar dengan baik melalui keterlibatan secara aktif. Keterlibatan dalam penggunaan bahasa secara aktif dapat dibuat lebih bermakna apabila dikaitkan dengan pengalaman dan hal-hal nyata dalam kehidupan anak. Asri Budiningsih (2005: 39) menyatakan bahwa untuk menghindari keterbatasan berfikir, anak perlu diberi gambaran konkrit sehingga ia mampu menelaah persoalan.

Pembelajaran kosakata bahasa Arab kepada siswa, sebaiknya didasarkan pada bagaimana mereka belajar bahasa. Hal ini dinyatakan oleh Hoskisson \& Tompkins (1987: 44) bahwa pembelajaran bahasa harus didasari pada bagaimana anak-anak belajar dan bagaimana mereka belajar bahasa. Guru perlu member kesempatan kepada siswa untuk menemukan cara belajarnya. Pertama, siswa perlu diajarkan bentuk bahasa lisan dan tulisan. Kedua, siswa perlu mendapat kesempatan untuk meniru bentuk-bentuk bahasa tersebut.

\section{Pembelajaran Kosakata Menggunakan Multimedia}

Komputer dalam pembelajaran bahasa menurut Tylor (Hoskisson \& Tompkins, 1987: 56) memiliki tiga fungsi, yaitu sebagai alat, tutor, dan tutee. Komputer sebagai alat dapat digunakan sebagai program untuk memproses kata-kata seperti menulis cerita, puisi, atau jenis karangan lainnya. Komputer sebagai tutor atau dikenal dengan istilah computer assisted instruction (CAI) dapat berfungsi sebagai alat bantu atau media pengajaran. Komputer sebagai tutee dapat digunakan dalam mempelajari bahasa komputer dan pemrograman komputer.

Menurut Wood (2001: 15), penggunaan multimedia pembelajaran berpotensi meningkatkan pembelajaran kosakata. Dalam multimedia pembelajaran dapat disajikan bentuk permainan, hyperlink, hypertext, dan animasi. Bentuk permainan dapat memberi stimulasi eksternal dan menampilkan berbagai bentuk grafik. Bentuk hyperlink memberi 
Cordova Jurnal

ISSN (P) 2302-3155,

(e) 2714-5808

Vol. 9, No. 12019
Jurnal kajian Bahasa dan Budaya terbit 2 kali setahun oleh UPT. Pusat Pengembangan

Bahasa (P2B) UIN Mataram. Tersedia online pada

https://journal.uinmataram.ac.id/index.php/cordova

kesempatan kepada siswa untuk memperoleh kata-kata baru dalam berbagai konteks melalui akses yang cepat ke teks dan grafik yang diinginkansiswa. Bentuk hypertext memungkinkan siswa mengklik katakata yang diinginkan untuk mendengar pengucapannya dan meningkatkan pemahaman terhadap kata-kata baru yang dipelajari. Sementara itu, animasi dapat meningkatkan pembelajarankosakata apabila digabungkan dengan narasi yang informatif dan menarik.

Nation (2001: 109) menyatakan bahwa pembelajaran kosakata dengan multimedia berpusat pada kondisi noticing, retrieval, dan generative use. (1) Noticing yaitu bentuk pembelajaran dengan menggunakan tulisan yang diberi warna, disorot, dan diberi cahaya; (2) Retrieval yaitu pembelajaran yang dilakukan dengan penundaan atau pemunculan petunjuk secara berangsur-angsur; (3) Generative use yaitu pembelajaran yang dilakukan dengan melengkapi kosakata dalam berbagai konteks dan bentuk seperti gambar, tulisan, dan suara.

Constantinescu (2007: 4) menyebutkan empat prinsip mengajar dalam pembelajaran bahasa berbantuan komputer untuk pengembangan kosakata. Pertama, guru harus memperhatikan ketersediaan alat-alat mengajar. Kedua, guru harus memberi penjelasan dalam bentuk teks dengan menggunakan multimedia. Ketiga, guru harus mengetahui jenisjenis materi online dalam pembelajaran bahasa Arab karena tidak semua materi tersebut dapat digunakan di dalam kelas. Keempat, guru harus menggunakan metode yang sesuai dan memanfaatkan multimedia dengan baik.

\section{METODE PENELITIAN}

Penelitian ini adalah penelitian pengembangan. Menurut Borg \& Gall (2003: 772), penelitian pengembangan adalah penelitian yang berorientasi untuk mengembangkan dan memvalidasi produk-produk yang digunakan dalam pendidikan. Hal senada juga dinyatakan oleh Gay (1981: 10) bahwa penelitian pengembangan bukan untuk membuat teori atau menguji teori melainkan untuk mengembangkan produkproduk yang efektif untuk digunakan di sekolah. 
Cordova Jurnal

ISSN (P) 2302-3155,

(e) 2714-5808

Vol. 9, No. 12019
Jurnal kajian Bahasa dan Budaya terbit 2 kali setahun oleh UPT. Pusat Pengembangan

Bahasa (P2B) UIN Mataram. Tersedia online pada

https://journal.uinmataram.ac.id/index.php/cordova

Dalam penelitian ini, model yang menjadi acuan adalah model penelitian pengembangan Borg \& Gall (2003: 775), model pengembangan desain pembelajaran Dick, Carey \& Carey (2005: 1), dan pengembangan produk model Luther, 1994 (Ariesto Hadi Sutopo, 2003: 32). Ketiga model pengembangan tersebut diadaptasi sehingga menghasilkan sebuah model pengembangan yang lebih sederhana, yang dijadikan sebagai landasan dalam penelitian. Secara garis besar model pengembangan ini dapat dilihat pada Gambar 1 berikut. 
Cordova Jurnal

ISSN (P) 2302-3155,

(e) 2714-5808

Vol. 9, No. 12019

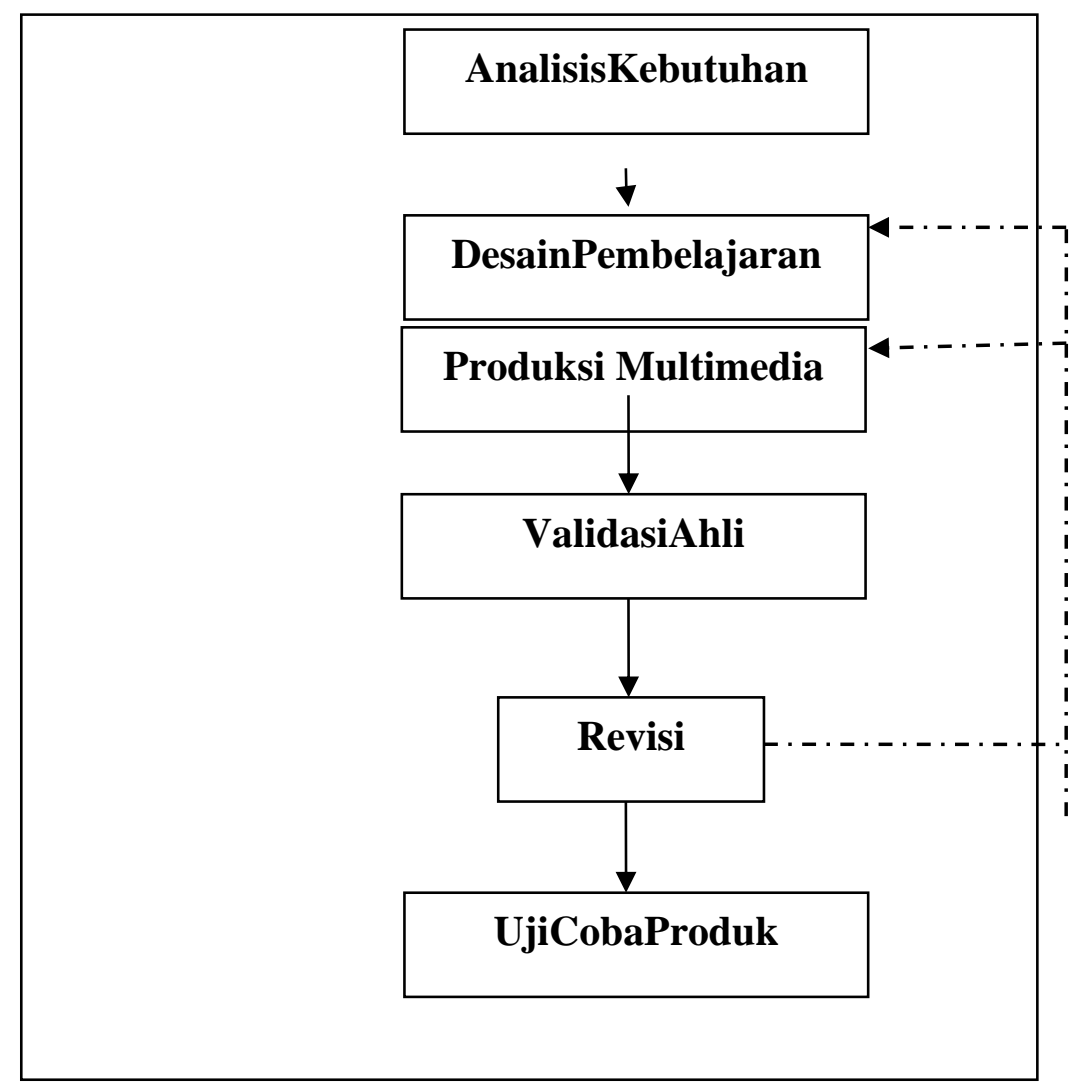

Gambar 1

Model Pengembangan Multimedia Pembelajaran

Diadaptasi dari Borg \& Gall (1983: 772), Dick \& Carey (2005: 1), dan Ariesto Hadi Sutopo (2003: 32)

Penelitian ini melalui enam tahap berikut. Pertama adalah tahap analisis kebutuhan. Tahap ini bertujuan untuk mengumpulkan informasi yang relevan dengan perlunya pengembangan multimedia pembelajaran kosakata bahasa Arab kelas 1 Pesma Al-Hikam.. Kedua adalah tahap desain pembelajaran. Tahap ini bertujuan untuk mengembangkan desain pembelajaran hingga menghasilkan silabus sebagai dasar untuk mengembangkan multimedia pembelajaran. Ketiga adalah tahap produksi/pengembangan multimedia. Tahap ini bertujuan untuk menghasilkan produk awal, dan selanjutnya dites atau dijalankan dalam komputer untuk memastikan apakah hasilnya sesuai dengan yang 
Cordova Jurnal

ISSN (P) 2302-3155,

(e) 2714-5808

Vol. 9, No. 12019
Jurnal kajian Bahasa dan Budaya terbit 2 kali setahun oleh UPT. Pusat Pengembangan

Bahasa (P2B) UIN Mataram. Tersedia online pada

https://journal.uinmataram.ac.id/index.php/cordova

diinginkan atau tidak. Keempat adalah tahap validasi ahli. Tahap ini bertujuan untuk mengetahui kelayakan produk yang dikembangkan. Kelima adalah melakukan revisi. Tahap ini bertujuan untuk meningkatkan kualitas produk berdasarkan saran revisi ahli materi dan ahli media. Keenam adalah melakukan uji coba produk. Tahap ini dilakukan untuk mengetahui daya tarik multimedia yang dikembangkan bagi siswa dan untuk memperoleh skor hasil pre-test dan post-test.

Validator penelitian terdiri dari satu orang ahli materi dan satu orang ahli

media. Ahli materi menilai aspek isi dan pembelajaran; ahli media menilai aspek

tampilan dan pemrograman. Subjek coba penelitian adalah siswa kelas I Pesma Al-Hikam Malang berjumlah dua puluh tiga siswa. Pada uji coba satu-satu melibatkan tiga siswa .

Sedangkan pada uji coba kelompok besar melibatkan dua puluh siswa .

Instrumen pengumpulan data yang digunakan adalah angket, pedoman observasi, dan soal pre-test dan post-test. Angket digunakan untuk memperoleh data yang berkaitan dengan kualitas kelayakan materi dan kualitas kelayakan media. Pedoman observasi digunakan sebagai panduan dalam melakukan observasi terhadap sikap siswa selama proses uji coba untuk mengetahui daya tarik produk bagi siswa. Soal pre-test dan post-test digunakan untuk mengetahui ketuntasan belajar siswa setelah menggunakan produk multimedia yang dikembangkan.

Jenis data penelitian ini adalah data kualitatif dan kuantitatif. Data dianalisis secara statistik deskriptif. Data kualitatif berupa komentar dan saran perbaikan produk dari ahli materi dan ahli media dianalisis dan dideskripsikan secara deskriptif kualitatif untuk merevisi produk yang dikembangkan. Data kuantitatif yakni data berupa skor penilaian ahli materi dan ahli media, skor hasil observasi, dan skor hasil pre-test dan post-test. Analisis data kuantitatif dijelaskan sebagai berikut. Pertama, data kuantitatif skor penilaian ahli materi dan ahli media 
Cordova Jurnal

ISSN (P) 2302-3155,

(e) 2714-5808

Vol. 9, No. 12019
Jurnal kajian Bahasa dan Budaya terbit 2 kali setahun oleh UPT. Pusat Pengembangan

Bahasa (P2B) UIN Mataram. Tersedia online pada

https://journal.uinmataram.ac.id/index.php/cordova

dianalisis secara deskriptif dengan acuan tabel konversi nilai yang diadaptasi dari Sukardjo (2005: 53-54), sehingga menghasilkan pedoman sebagaimana disajikan dalam Tabel 1 berikut.

Tabel 1

Pedoman Konversi Data Kuantitatif ke Data Kualitatif dengan Skala 5

\begin{tabular}{|l|l|l|}
\hline Nilai & Interval skor & Kriteria \\
\hline \multicolumn{1}{|c|}{$\mathrm{A}$} & $\mathrm{X}>4,21$ & Sangat baik \\
\hline $\mathrm{B}$ & $3,40<\mathrm{X} \leq 4,21$ & Baik \\
\hline $\mathrm{C}$ & $2,60<\mathrm{X} \leq 3,40$ & Cukup \\
\hline $\mathrm{D}$ & $1,79<\mathrm{X} \leq 2,60$ & Kurang \\
\hline $\mathrm{E}$ & $\mathrm{X} \leq 1,79$ & Sangat kurang \\
\hline
\end{tabular}

Keterangan:

Skor maksimal ideal $\quad=5 \times \mathrm{i}=1 / 2(5+1)=3$

Skor minimal ideal $=1 \mathrm{SBi}=1 / 6(5-1)=0,67$

Kedua, data kuantitatif daya tarik produk hasil observasi diubah menjadi data kualitatif dengan berpedoman pada konversi nilai yang diadaptasi dari Sukardjo (2005: 53-54) seperti pada Tabel 12 berikut.

Tabel 2

Pedoman Konversi Data Kuantitatif ke Data Kualitatif untuk Daya Tarik Media yang Dikembangkan

\begin{tabular}{|l|l|l|}
\hline ai & Interval skor & Kriteria \\
\hline A & $X>12,806$ & Sangat menarik \\
\hline B & $9,602<X \leq 12,806$ & Menarik \\
\hline C & $6,398<X \leq 9,602$ & Cukup menarik \\
\hline D & $3,194<X \leq 6,398$ & Kurang menarik \\
\hline E & $X \leq 3,194$ & $\begin{array}{l}\text { Sangat kurang } \\
\text { menarik }\end{array}$ \\
\hline
\end{tabular}


Cordova Jurnal

ISSN (P) 2302-3155,

(e) 2714-5808

Vol. 9, No. 12019
Jurnal kajian Bahasa dan Budaya terbit 2 kali setahun oleh UPT. Pusat Pengembangan

Bahasa (P2B) UIN Mataram. Tersedia online pada

https://journal.uinmataram.ac.id/index.php/cordova

Keterangan:

Skor maksimal $=1 \times 16=16 \times \mathrm{i}=1 / 2(16+0)=8$

Skor minimal $=0 \times 16=0 \mathrm{SBi}=1 / 6(16-0)=2,67$

$\mathrm{X}=$ Skor aktual.

Ketiga, Data skor hasil pre-test dan post-test dianalisis dengan menghitung persentase siswa yang telah memperoleh nilai $\leq 70$ dan mengubah data kuantitatif persentase ketuntasan belajar menjadi data kualitatif berpedoman pada acuan konversi nilai menurut Bloom, Madaus \& Hastings (Tanwey Gerson Ratumanan \& Theresia Laurens, 2003: 19), yang disajikan dalam Tabel 3 berikut.

Tabel 3

Konversi Persentase Ketuntasan Belajar Menjadi Data Kualitatif

\begin{tabular}{|l|l|}
\hline Persentase (\%) & Kriteria \\
\hline $90 \leq X$ & Sangat baik \\
\hline $80 \leq X<90$ & Baik \\
\hline $70 \leq X<80$ & Cukup \\
\hline $60 \leq X<70$ & Kurang \\
\hline$X<60$ & Sangat kurang \\
\hline
\end{tabular}

\section{HASIL DAN PEMBAHASAN}

Pengembangan produk multimedia pembelajaran kosakata bahasa Arab kelas I Pesma Al-Hikam Malang diawali dengan analisis kebutuhan, pengembangan desain pembelajaran, pengembangan produk, validasi ahli, revisi produk, dan kemudian ujicoba produk. Berdasarkan langkah-langkah tersebut telah dihasilkan data penelitian yang menjadi hasil dan bahasan penelitian, yakni: (1) data hasil validasi ahli, (2) data hasil

observasi, dan (3) data hasil pre-test dan post-test. Adapun hasil penelitian akan

dibahas sebagai berikut. 
Cordova Jurnal

ISSN (P) 2302-3155,

(e) 2714-5808

Vol. 9, No. 12019
Jurnal kajian Bahasa dan Budaya terbit 2 kali setahun oleh UPT. Pusat Pengembangan

Bahasa (P2B) UIN Mataram. Tersedia online pada

https://journal.uinmataram.ac.id/index.php/cordova

\section{Data Validasi Ahli}

Data validasi ahli yaitu data yang diperoleh berdasarkan penilaian ahli materi

dan ahli media melalui angket. Ahli materi menilai aspek isi dan pembelajaran, ahli

media menilai aspek tampilan dan pemrograman. Setelah dilakukan analisis, diperoleh rata-rata skor penilaian ahli materi untuk aspek isi sebesar 3,75 dan untuk aspek pembelajaran sebesar 3,71. Dengan menggunakan rentang skor 1 sampai 5, rata-rata skor penilaian ahli materi untuk aspek isi dan pembelajaran sesuai dengan pedoman konversi nilai skala 5 tergolong kriteria baik.

Sementara itu, rata-rata skor penilaian ahli media untuk aspek tampilan sebesar 3,87 dan aspek pemrograman sebesar 3,75. Rata-rata skor penilaian ahli media pada aspek tampilan dan pemrograman tergolong kriteria baik. Dengan hasil-hasil tersebut di atas, disimpulkan bahwa multimedia pembelajaran kosakata bahasa Arab kelas I Pesma Al-Hikam Malang layak digunakan dalam pembelajaran baik ditinjau dari aspek isi dan pembelajaran maupun dari aspek tampilan dan pemrograman karena memperoleh nilai rata-rata keseluruhan " $\mathrm{B}$ " atau tergolong kriteria "Baik". Kesimpulan ini diambil sesuai dengan nilai kelayakan yang ditetapkan dalam penelitian ini yaitu apabila ahli materi dan ahli media memberi nilai minimal " $C$ " atau dengan kriteria "cukup", produk yang dikembangkan dianggap layak digunakan dalam pembelajaran.

\section{Data Hasil Observasi}

Berdasarkan hasil uji coba satu-satu diketahui bahwa dua siswa dari tiga siswa

menunjukkan daya tarik multimedia yang dikembangkan pada kriteria "sangat menarik", sedangkan satu siswa menunjukkan daya tarik media pada criteria "menarik". Pada uji coba kelompok besar diketahui dua belas siswa dari dua puluh siswa yang diobservasi menunjukkan daya tarik produk pada kriteria "sangat menarik". Sedangkan delapan siswa menunjukkan daya tarik produk pada criteria "menarik". Kriteria daya 
Cordova Jurnal

ISSN (P) 2302-3155,

(e) 2714-5808

Vol. 9, No. 12019
Jurnal kajian Bahasa dan Budaya terbit 2 kali setahun oleh UPT. Pusat Pengembangan

Bahasa (P2B) UIN Mataram. Tersedia online pada

https://journal.uinmataram.ac.id/index.php/cordova

tarik diperoleh berdasarkan pada konversi data kuantitatif ke data kualitatif skala 5 menurut Sukardjo (2005: 53-54). Dengan hasil-hasil pada uji coba satu-satu dan uji coba kelompok besar tersebut, dapat disimpulkan bahwa produk yang dikembangkan "sangat menarik". Kesimpulan ini diambil karena lebih dari setengah jumlah siswa menunjukkan daya tarik produk berada pada kriteria "sangat menarik".

3. Data Hasil Pre-test dan Post-test

Tujuan melakukan pre-test dan post-test adalah memperoleh data skor siswa untuk mengetahui ketuntasan belajar siswa setelah menggunakan produk yang dikembangkan. Berdasarkan standar nilai ketuntasan belajar minimal yang telah ditetapkan yaitu $\geq 70$, diketahui bahwa dalam uji coba kelompok besar dari 20 siswa, terdapat 19 siswa yang tuntas belajar kosakata bahasa Inggris dan hanya satu siswa yang tidak tuntas belajar kosakata bahasa Arab. Dengan demikian, persentase ketuntasan belajar siswa adalah 19: $20 \times 100 \%=95 \%$. Selanjutnya, persentase ketuntasan ini dikonversi ke data kualitatif untuk mengetahui kriterianya. Dengan berpedoman pada konversi persentase ketuntasan belajar menjadi data kualitatif, diketahui ketuntasan belajar 95\% termasuk kriteria "sangat baik". Dengan hasil tersebut, dapat disimpulkan bahwa multimedia pembelajaran kosakata bahasa Arab kelas I Pesma Al-Hikam Malang berdampak positif terhadap ketuntasan belajar siswa dan membantu memudahkan siswa mempelajari kosakata bahasa Arab.

\section{KESIMPULAN}

Hasil penelitian pengembangan ini dapat disimpulkan sebagai berikut.

Pertama, pengembangan multimedia dalam pembelajaran kosakata bahasa Arab kelas I Pesma Al-Hikam Malang telah dilakukan melalui enam tahap, yaitu: (1) melakukan analisis kebutuhan, (2) mengembangkan desain pembelajaran, (3) mengembangkan produk multimedia pembelajaran, (4) melakukan validasi ahli, (5) melakukan revisi, dan (6) melakukan uji coba. 
Cordova Jurnal

ISSN (P) 2302-3155,

(e) 2714-5808

Vol. 9, No. 12019
Jurnal kajian Bahasa dan Budaya terbit 2 kali setahun oleh UPT. Pusat Pengembangan

Bahasa (P2B) UIN Mataram. Tersedia online pada

https://journal.uinmataram.ac.id/index.php/cordova

Kedua, ditinjau dari aspek isi dan aspek pembelajaran, kualitas multimedia yang dikembangkan dinilai "baik" oleh ahli materi. Kriteria "baik" ini diketahui melalui tabel konversi nilai skala 5. Rata-rata skor penilaian ahli materi pada aspek isi 20 adalah 3,75 dan rata-rata skor penilaian ahli materi pada aspek pembelajaran adalah 3,71.

Ketiga, ditinjau dari aspek tampilan dan aspek pemograman, kualitas multimedia pembelajaran yang dikembangkan dinilai "baik" oleh ahli media. Ahli media memberi penilaian pada aspek tampilan dengan rata-rata skor sebesar 3,87 dan aspek pemrograman dengan ratarata skor sebesar 3,75.

Keempat, berdasarkan hasil observasi, disimpulkan bahwa daya tarik produk "sangat menarik", karena lebih dari setengah jumlah siswa menyatakan bahwa produk "sangat menarik". Kriteria daya tarik ini diketahui melalui tabel pedoman konversi data kuantitatif ke data kualitatif untuk daya tarik media yang dikembangkan.

Kelima, penggunaan multimedia mempunyai dampak positif terhadap ketuntasan belajar siswa. Dari dua puluh siswa yang telah mengikuti uji coba kelompok besar terdapat satu siswa yang tidak tuntas belajar kosakata bahasa Arab dan 19 siswa (95\%) yang tuntas belajar dengan rata-rata skor 16,25 atau memperoleh nilai 81,25 dari nilai maksimal 100. Ketuntasan belajar ini tergolong "sangat baik". 


\section{Daftar Pustaka}

Abu Bakar Sulaiman., A. Gani. \& Syafri K. (1986). Kosa kata bahasa Melayu Riau. Jakarta: Pusat Pembinaan dan Pengembangan Bahasa Departemen Pendidikan dan Kebudayaan.

Agnew, P. W., Kellerman, A. S. \& Meyer, M. J. (1996). Multimedia in the classroom. Boston: Allyn and Bacon.

Arief S. Sadiman, et al. (2006). Media pendidikan: Pengertian, pengembangan dan pemanfaatannya. Jakarta: PT Raja Grafindo Persada.

Ariesto Hadi Sutopo. (2003). Multimedia interaktif dengan flash. Yogyakarta: Graha Ilmu.

Asri Budiningsih. (2005). Belajar dan membelajarkan. Jakarta: PT Rineka Cipta.

Borg, W. R. \& Gall, M. D. (2003). Educational research: an introduction (7th ed.).New York: Longman, Inc.

Constantinescu, A. I. (2007). Using technology to assist in vocabulary acquisition and reading comprehension. The Internet TESL Journal, Vol. XIII, No. 2, February 2007. Diambil tanggal 7 September 2007, dari http://iteslj.org/Articles/Constantinescu-Vocabulary.html

Dick, W., Carey, L. \& Carey, J. O. (2005). The systematic design of instruction. Boston: Harper Collin College Publisher.

Gay, L R. (1981). Educational research: Competencies for analysis $\mathcal{E}$ application. (2nd ed.). Colombus: Charlie E. Merrill Publishing Co. 
Cordova Jurnal

ISSN (P) 2302-3155,

(e) 2714-5808

Vol. 9, No. 12019
Jurnal kajian Bahasa dan Budaya terbit 2 kali setahun oleh UPT. Pusat Pengembangan

Bahasa (P2B) UIN Mataram. Tersedia online pada

https://journal.uinmataram.ac.id/index.php/cordova

Hackbarth, S. (1996). The educational technology handbook: A comprehensive Guide. Englewood Cliffs: Educational Technology Publication, Inc.

Herman Dwi Surjono. (1995). Pengembangan computer assisted instruction (CAI) untuk pembelajaran elektronika [Versi elektronik]. Jurnal Kependidikan. No.2 (XXV): 95-106.

- (1999). Pengembangan program CAI dengan strategi remediasi kesalahan [Versi elektronik]. Jurnal Kependidikan. I (XXIX): 45-58.

Hoskisson, K. \& Tompkins, G. E. (1987) Language arts: Content and teaching strategies. Melbourne: Merill Publishing Company.

Lado, R. (1979). Language teaching. A scientific approach. Bombay-New Delhi: Tata McGraw-Hill Publshing Co.LTD.

Nation, I. S. P. (2001). Learning vocabulary in another language. Cambridge: Cambridge University Press.

Nunan, D. (1991). Language teaching methodology: A textbook for teachers. Sydney:

Prentice Hall International (UK) Ltd.

Philips, R. (1997). A practical guide for educational applications. London: Kogan Page limited.

Pikulski, J. J. \& Templeton, S. (2004). Teaching and developing vocabulary: key tolong-term reading success. Diambil tanggal 4 September 2007, dari

http://www.eduplace.com/marketing/nc/pdf/authorpages.pd $\underline{\mathrm{f}}$ 
Cordova Jurnal

ISSN (P) 2302-3155,

(e) 2714-5808

Vol. 9, No. 12019
Jurnal kajian Bahasa dan Budaya terbit 2 kali setahun oleh UPT. Pusat Pengembangan

Bahasa (P2B) UIN Mataram. Tersedia online pada

https://journal.uinmataram.ac.id/index.php/cordova

Sitorus, R. H. (1993). Cara mudah belajar bahasa Inggris: English vocabulary. Bandung: CV. Pionir Jaya.

Sukardjo. (2005). Evaluasi pembelajaran. Diktat mata kuliah evaluasi pembelajaran. Prodi TP PPs UNY. Tidak diterbitkan.

Sunaryo Soenarto. (2005). Pengembangan multimedia pembelajaran interaktif matakuliah tata hidang. Inotek: Jurnal inovasi dan aplikasi teknologi.Volume 9, Nomor 1, Februari 2005.

Tan Seng Chee \& Angela F. L. Wong (Eds.) (2003). Teaching and learning with technology: An asia-pacific perspective. Singapore: Prentice Hall.

Tarigan, H. G. (1986). Pengajaran kosakata. Bandung: Penerbit Angkasa.

Wood, J. (2001). Can software support children's vocabulary development? [versi elektronik]. Journal of Language Learning \&Technology, 5, 166-265. 